\title{
RESIDUAL METHOD OF PROPERTY VALUATION
}

\author{
Andrzej Skarzyński \\ Institute of Structural Engineering, Division of Construction Engineering Management, \\ Poznan University of Technology, Piotrowo 5, 60-965 Poznan, Poland \\ E-mail: andrzej.skarzynski@ikb.poznan.pl
}

Received 12 December 2005; accepted 15 September 2006

\begin{abstract}
In the paper the residual method as one of the methods used for property valuation by mixed approach is presented. The paper contains the description of the most often used applications of the residual method and two examples of the practical usage of this method. The first example relates to the valuation of a family house being built for the purpose of obtaining a mortage loan to complete construction work. The second example concerns the valuation of an office building considered for purchasing by a potential buyer. The paper ends with the conclusions concerning the conditions of property valuation.
\end{abstract}

Keywords: real estate valuation; approaches, methods and techniques of valuation.

\section{Introduction}

Residual method of property valuation is used in Poland [1] to define market value of real estate, if construction work is being done on the estate, in a way of building, rebuilding, extension, refurbishing, assembly or modernization work on the estate.

The value of the estate as it currently is $\left(W_{N S t}\right)$, is defined as the difference between the value of the estate after the above mentioned work has been completed $\left(W_{N u}\right)$, and the value of average cost of the work $\left(K_{u}\right)$, taking into consideration the investor's profit generated on the market from a comparable real estate $\left(Z_{i}\right)$.

A broader definition in this respect is given, namely that the value of the estate can be defined using the residual method for land valuation, for valuating land and its component parts, or separately for the component parts of land.

The residual method is most often used for:

- performing analyses of profitability of projects regarding the envisaged building, rebuilding, extension, refurbishing, assembly or modernization work on the estate, etc.,

- defining the value of land as a part of the whole estate,

- defining the value of a building as a part of the whole estate.
Valuation of property by means of the residual method can be attained in the combination with other methods, using comparable approach, revenue generating approach, and cost approach. Therefore, among other methods used in Poland, the residual method is classified to the group of mixed approach [1].

The residual technique is most useful in valuating real estate which has a chance for development as the result of additional investment in rebuilding, extension, modernization, etc., and which can bring return of the capital and bring profit. The place of the residual method amongst other methods of property valuation is shown in Table 1 [2-5].

The residual method discussed in this article can play a decisive role in making investment related decisions. Some circumstances involved are:

- valuation of real estate where finishing or modernisation work requires obtaining a bank loan;

- valuation of real estate in order to purchase or sell real estate which requires modernisation, refurbishing, or other work leading to amelioration of standards of the real estate, for instance by upgrading the class of a hotel or office building.

Below there are two examples of applying the residual technique to valuate two different properties and buildings for two different purposes. In both instances, the element of investor's profit $\left(Z_{i}\right)$ has been ignored. 
Table 1. The approaches, the method and techniques used in Poland for property valuation

\begin{tabular}{|c|c|c|c|c|c|c|}
\hline \multicolumn{3}{|c|}{ Market value } & \multicolumn{2}{|c|}{ Reproduction Value } & \multicolumn{2}{|c|}{ Mixed approach } \\
\hline $\begin{array}{l}\text { 1. Appraisal by } \\
\text { comparison or } \\
\text { comparable }\end{array}$ & \multicolumn{2}{|c|}{$\begin{array}{l}\text { 2. Appraisal by capitalization or } \\
\text { revenue generating approach }\end{array}$} & \multicolumn{2}{|c|}{ 3. Cost approach } & \multicolumn{2}{|c|}{ 4. Mixed approach } \\
\hline METHODS & METHODS & TECHNIQUES & METHODS & TECHNIQUES & METHODS & TECHNIQUES \\
\hline 1 & 2 & 3 & 4 & 5 & 6 & 7 \\
\hline $\begin{array}{l}\text { 1.1. The method of } \\
\text { comparing pairs }\end{array}$ & $\begin{array}{l}\text { 2.1. The } \\
\text { investment } \\
\text { method }\end{array}$ & $\begin{array}{l}\text { 2.1.1. The simple } \\
\text { capitalization } \\
\text { 2.1.2. The } \\
\text { discounted cash } \\
\text { flow }\end{array}$ & $\begin{array}{l}3.1 \text {. The } \\
\text { method of } \\
\text { reproduction } \\
\text { costs }\end{array}$ & $\begin{array}{l}\text { 3.1.1. Detailed } \\
\text { 3.1.2. Integrated } \\
\text { elements } \\
\text { 3.1.3. Indexes }\end{array}$ & $\begin{array}{l}\text { 4.1. THE } \\
\text { RESIDUAL } \\
\text { METHOD }\end{array}$ & $\begin{array}{l}\text { The mixed } \\
\text { approach can } \\
\text { contain the } \\
\text { elements of the } \\
\text { approaches: }\end{array}$ \\
\hline $\begin{array}{l}1.2 \text {. The method of } \\
\text { average price } \\
\text { correction }\end{array}$ & $\begin{array}{l}2.2 \text {. The } \\
\text { profits method }\end{array}$ & $\begin{array}{l}\text { 2.2.1. The simple } \\
\text { capitalization } \\
2.2 .2 \text {. The } \\
\text { discounted cash } \\
\text { flow }\end{array}$ & $\begin{array}{l}\text { 3.2. The } \\
\text { method of } \\
\text { replacement } \\
\text { costs }\end{array}$ & $\begin{array}{l}\text { 3.2.1. Detailed } \\
\text { 3.2.2. Integrated } \\
\text { elements } \\
\text { 3.2.3. Indexes }\end{array}$ & $\begin{array}{l}\text { 4.2. The } \\
\text { method of } \\
\text { liquidation } \\
\text { costs }\end{array}$ & $\begin{array}{l}\text { - comparable } \\
\text { - revenue } \\
\text { generating } \\
\text { - cost }\end{array}$ \\
\hline $\begin{array}{l}\text { 1.3. The method of } \\
\text { statistical analysis of } \\
\text { the market }\end{array}$ & & & & & $\begin{array}{l}\text { 4.3. The } \\
\text { method of } \\
\text { estimaited } \\
\text { farmland } \\
\text { indexes }\end{array}$ & \\
\hline
\end{tabular}

Example 1: Valuation of a family house being built for the purpose of obtaining a mortgage loan to complete construction work

At the time of valuation the construction work on the building in question designed to be built by traditional technology had been stopped at the open stage (without windows, doors and roofing, and excluding plumbing, heating electrical systems and finishing work). Therefore, the owner applied to the bank for a mortgage to finish the work. One of the preconditions of granting the mortgage was to present the valuation done by a valuer in order to assess the current value of the property. The value of the property at the current stage of progress of construction work was to give the basis for security on which the loan was to be granted.

The property valuation employed the [4] residual method. The value of the property $\left(W_{N u}\right)$, including the finished building $\left(W_{B}\right)$ was defined using the following formula (1):

$$
W_{N u}=W_{G}+W_{B} .
$$

The value of the property, which will embrace the building where construction work will be completed $\left(W_{N u}\right)$, was assessed using the comparable approach, by means of the method of comparing pairs of real estate and defined at 242 418 PLN.

The value of land $\left(W_{G}\right)$ was also assessed using the comparable approach and the method of comparing pairs and defined at 22750 PLN.

The stage of the advancement of construction work $\left(W_{B S t}\right)$ was estimated using the tables of costs of unit elements of construction work, again comparing the building with similar buildings, and defined at the level of $40 \%$.
Therefore, the cost of the remaining construction work to be done on the building was $60 \%$ of the cost of the whole building.

In order to calculate the value of the building after the construction work will be completed, the formula (1) was transformed in the following way (1):

$$
\begin{gathered}
W_{B}=W_{N u}-W_{G}, \\
W_{B}=242418-22750=219668 \text { PLN. }
\end{gathered}
$$

The value of the building as it was at the time of valuation $\left(W_{B S t}\right)$ was, therefore:

$$
W_{B S t}=W_{B} \times\left(1-\frac{60 \%}{100 \%}\right)=219668 \times 0,4=87867 \text { PLN. }
$$

The value of the property as it was at the time of valuation $\left(W_{N S t}\right)$ was defined, according to the above formula (3):

$$
\begin{gathered}
W_{N S t}=W_{G}+W_{B S t}, \\
W_{N S t}=22750+87867=110617 \text { PLN. }
\end{gathered}
$$

The value of property as it was $\left(W_{N S t}\right)$, calculated using formula (3), was the basis for estimating the value of security on which the mortgage loan to complete the construction work would be granted.

Example 2: Valuation of an office building considered for purchasing by a potential buyer

The valuated building was erected in 1975. In 1995 its owners changed. In 1996, it was supposed to undergo modernization in accordance with a modernization design, but the work was done only partially, while some jobs, which were supposed to have been done, were not done at all.

Therefore, in the course of valuation, one of the factors 
which had to be taken into consideration, was the capital which the future owner will have to invest in order to meet the standards required for office buildings. Furthermore, the owner offered only a price for the building itself. The price did not include the value of land which had to be estimated.

The value of the property after amendments $\left(W_{N u}\right)$, in other words, after the completion of the necessary modernization work was estimated using the following formula (4):

$$
W_{N u}=W_{G}+W_{B S t}+K_{U},
$$

where: $W_{G}-$ the value of land (the value of long term lease of the separated plot of land); $W_{B S t-}$ the value of the building at the time of valuation; $K_{U}$ - the cost of completing necessary modernisation, including the cost of indispensable construction work $\left(K_{B}\right)$, the cost of procuring technical documentation and supervision of construction work $\left(K_{P N}\right)$ at the level of $5 \%$ of $K_{B}$ and the cost of financing of the modernisation work $\left(K_{F}\right)$.

$$
K_{U}=K_{B}+K_{P N}+K_{F} .
$$

In order to assess the value of the building itself as it was $\left(W_{B S t}\right)$, formula (4) was transformed into formula (6):

$$
W_{B S t}=W_{N u}-W_{G}-K_{U} .
$$

The value of land $\left(W_{G}\right)$ for the property in question was assessed using the comparable approach, i.e. the method of average price correction, and defined as 205300 PLN.

The value of the property, including land after necessary modernisation work has been completed $\left(W_{N u}\right)$, has been calculated using revenue generating approach, investment method, and simple capitalisation technique, at 3263311 PLN.

The cost of necessary modernisation work $\left(K_{B}\right)$, following detailed valuation of the current state of the property, defining the scope of necessary modernisation work, has arrived using the cost approach and detailed technique. $K_{B}$ cost has been calculated at 697059 PLN.

The cost of technical design and supervision $\left(K_{P N}\right)$ has been calculated at $5 \%$ of the construction work $\left(K_{B}\right)$ :

$$
K_{P N}=0,05 \times 697=34853 \text { PLN. }
$$

The cost of financing modernisation work $\left(K_{F}\right)$ has been assumed for $1 / 2$ of average time of construction work, at the annual interest rate of $15 \%$ of $K_{B}$ and $K_{P N}$ ):

$$
K_{F}=0,15 \times(697059+34853) \times 0,5=54893 \text { PLN } .
$$

The cost of necessary modernisation work $\left(K_{U}\right)$ has been calculated using formula (5):

$$
K_{U}=697059+34853+54893=786805 \text { PLN. }
$$

The value of the building itself as it was at the time of valuation $\left(W_{B S t}\right)$ has been defined by formula (6):

$$
W_{B S t}=3263311-205300-786805=2271206 \text { PLN. }
$$

The presented methodology of assessing value of real estate using the residual method highlights the structure of cost components on condition that $W_{\mathrm{Nu}}=100 \%$.

As for the case under consideration, the structure is as follows:

$$
W_{G}=6,29 \% ; W_{B S t}=69,60 \% \text { and } K_{U}=24,11 \% .
$$

\section{Conclusions}

1. Residual method of property valuation is an important tool while taking action during investment processes in construction. The action may be related to small buildings (example 1), large buildings (example 2), or groups of buildings in complex investment processes.

2. The application of the residual method requires the real estate valuer to be familiar with a variety of approaches for valuation, i.e. the comparable properties approach, the revenue generating approach, and the cost approach.

3. The application of the residual method requires also skills and experience in assessing technical condition of buildings, and the ability to calculate the scope of work to be done, and its proper valuation.

4. Correct application of the residual method requires sound knowledge of the local real estate market on the part of the property valuer, as far as transaction prices and rent levels are concerned, as well as knowledge about average costs of construction work.

\section{References}

1. Central Government Regulation of 21 September 2004 concerning real estate valuation and procuring real estate valuation reports (Rozporządzenie Rady Ministrów z dnia 21.09.2004 w sprawie wyceny nieruchomości i sporządzania operatu szacunkowego). Dz. U. Nr 207, poz. 2109 (in Polish).

2. Central Government Regulation of 21 November 2002 concerning detailed principles of real estate valuation and procuring real estate valuation reports (Rozporządzenie Rady Ministrów z dnia 27.11.2002 r. w sprawie szczegółowych zasad wyceny nieruchomości oraz zasad i trybu sporządzania operatu szacunkowego). Dz. U. Nr 230, poz. 1924 (in Polish).

3. Boczek, Z. J. Real estate valuation (Wycena nieruchomości). Currenda Sp. z o.o., Sopot, 2001 (in Polish).

4. Skarzyński, A. Valuation report concerning the assessment of market value of property situated in Poznań, at Osiedle Wilczy Młyn (Operat szacunkowy dotyczący ustalenia wartości rynkowej nieruchomości położonej w Poznaniu na Osiedlu Wilczy Młyn). Poznań, 1996 (in Polish).

5. Skarzyński, A. Real estate valuation report concerning a plot of land and a building situated on the land (Operat szacunkowy nieruchomości gruntowej oraz znajdującego się na tym gruncie budynku). Poznań, 2003 (in Polish). 


\section{NEKILNOJAMOJO TURTO VERTINIMAS LIKUTINĖS VERTÉS METODU}

\section{A. Skarzynski}

\section{Santrauka}

Straipsnyje nagrinejjamas vienas mišraus tipo likutinès vertės metodas nekilnojamajam turtui vertinti. Aprašyti šio metodo dažniausiai pasitaikantys atvejai ir pateikti du praktiniai metodo taikymo pavyzdžiai. Pirmajame pavyzdyje aprašytas individualaus gyvenamojo namo įvertinimo atvejis, kai norima paimti paskolą pradètiems statybos darbams baigti. Antrajame pavyzdyje įvertinamas biuro pastatas, kuriam ieškoma potencialaus pirkejjo. Straipsnio išvadose aptariami kai kurie nekilnojamojo turto vertinimo aspektai.

Reikšminiai žodžiai: nekilnojamojo turto vertinimas, požiūriai, vertinimo metodai ir technika.

Andrzej SKARZYŃSKI. Doctor Habil, Professor of Poznań University of Technology, director of post-diploma studies of real estate valuation, ul. Piotrowo 5, 60 - 965 Poznań, Poland. Publications: Author and co-autor of more than 90 papers, articles and books. Research visits: CEBTP in Paris (France) - technology of monolithic concrete construction ( 8 months - 1976) and ISEL in Lisbon (Portugal) - organisation of civil egineering works (1 month - 1994). Member of the Division of Construction Management in the Civil Engineering Committee of Polish Academy of Sciences. Research interests: construction engineering, construction management and economics, real estate valuation. 